\title{
Extraction of Proteins from Mackerel Fish Processing Waste Using Alcalase Enzyme
}

Ramakrishnan VV, Ghaly AE*, Brooks MS, Budge SM

Department of Process Engineering and Applied Science, Dalhousie University, Halifax, Nova Scotia, Canada

\begin{abstract}
Fish proteins are found in the flesh, head, frames, fin, tail, skin and guts of the fish in varying quantities. Unutilized fish and fish processing waste can be used to produce fish proteins which contain amino acids and many bioactive peptides. After removing the fish flesh during the fish processing operation, all other parts are considered wastes which are not properly utilized. The aim of this study was to evaluate the enzymatic extraction of protein from mackerel fish processing waste. Enzymatic extraction of proteins was carried out using alcalase enzyme at three concentrations $(0.5$, 1 or $2 \%)$ and four hydrolysis times (1, 2, 3 and $4 \mathrm{~h}$ ). The fish protein hydrolysate was dried using a spray dryer to obtain protein powder. The highest protein yield $(76.30 \%$ from whole fish and $74.53 \%$ from the frame) was obtained using $2.0 \%$ enzyme concentration after $4 \mathrm{~h}$ of hydrolysis. The results showed that increasing the enzyme concentration from 0.5 to $2 \%(400 \%)$ increased the protein yield by $3.13-43.52 \%$ depending upon the fish part and reaction time used. Increasing the enzyme concentration by 4 fold for a small increase in protein yield may appear unjustified. Therefore, the enzyme concentration of $0.5 \%$ should be used for the protein extraction unless the enzyme is recycled or an immobilized reactor is used in order to reduce the cost associated with the enzyme. Also, increasing the hydrolysis time from 1 to 4 $\mathrm{h}(400 \%)$ increased the protein yield by $16.45-50.82 \%$ depending upon the fish part and enzyme concentration used. Increasing the hydrolysis time by 4 fold for a small increase in protein yield will increase the capital and operating costs of protein production. A shorter hydrolysis time will allow more throughput and/or reduce the volume of the reactor thereby reducing the cost of protein extraction. Therefore, a $1 \mathrm{~h}$ reaction time for protein extraction is recommended. The results showed that the combined fish waste can be used for protein extraction without any segregation.
\end{abstract}

Keywords: Fish; Fish processing; Fish waste; Protein; Oil; Alcalase; Spray drying; Zipper mechanism

\section{Introduction}

Canada is currently ranked $19^{\text {th }}$ in marine fisheries and $26^{\text {th }}$ in aquaculture production in the world. Fish production is one of the major industries in Canada with total landings of 876,277 tones having a value of $\$ 2,165,608$ in the year 2011. Aquaculture production contributed 163,036 tones which is about $15.6 \%$ of the total fish production [1]. Statistics Canada [2] reported that in the year 2011/2012, 55,587 metric tons of fish waste was produced in Canada.

However, there are several environmental issues related to the fishing industry. The Government of Canada has granted permission to the provincial fisheries to dump fish waste into the ocean. This included 459 permits to the Atlantic fisheries to dump 732,770 tones, 40 permits to the Quebec fisheries to dump 22,520 tones and 1 permit to the Pacific fisheries and Yukon to dump 2,800 tons of fish waste in the sea during the period of April 2000 to March 2011 [3]. In addition, the aquaculture industry generates significant amounts of fish wastes that pollute surface and ground water. These organic wastes include nitrates and phosphates and can stimulate algal bloom resulting in oxygen depletion and destruction of aquatic life [4]. However, the underutilized and spoiled whole fish and fish processing wastes can be utilized for the production of value added products such as proteins, amino acids, biodiesel, glycerol, omega-3-fatty acids, meal, silage, lactic acid, ethanol and methanol.

Fish protein concentrates (FPC) are usually prepared from whole fish or fish waste by removing most of the water and fat contents from minced fish by chemical processes. The process is quite complicated and is carried out with solvents such as ethanol or propanol at $75^{\circ} \mathrm{C}$. This process yields FPC having $80 \%$ protein content. FPC is made commercially in several countries including Canada, USA, UK, Norway, Sweden, Morocco, South Africa, Chile and Peru. However, the main problems with this process are: (a) the fishy flavor of the product, (b) some of the flavor is lost during this process, (c) the presence of fat which causes rancidity, (d) oxidized fat is undesirable in the final product and (e) complete removal of solvent is difficult [5].

Enzymatic hydrolysis of underutilized and spoiled fish was previously carried out to extract proteins for use as animal feed or fertilizer [6-8]. However, fish processing waste can also be converted into proteins for human consumption [9-12] and oil for bio-energy [13-16]. The work in this study involves a laboratory scale enzymatic hydrolysis of whole mackerel fish and fish waste (frames, head, fin, tail, skin and gut) for the production of protein and further hydrolysis to amino acids.

\section{Objectives}

The main aim of this study was to evaluate the enzymatic extraction of protein from whole mackerel fish and fish parts (whole fish, head, fin, tail, skin and gut, and frames). The specific objectives were: (a) to study the effectiveness at various concentrations of the enzyme alcalase $(0.5,1$ and $2 \%)$ for extracting protein from fish and fish waste and (b) to study the effect of the hydrolysis time (1, 2, 3 and $4 \mathrm{~h}$ ) on the extraction yield of protein.

*Corresponding author: Ghaly AE, Professor, Department of Process Engineering and Applied Science, Faculty of Engineering, Dalhousie University, Halifax, Nova Scotia, Canada, Tel: (902)494-6014; E-mail: abdel.ghaly@dal.ca

Received June 26, 2013; Accepted July 29, 2013; Published August 05, 2013

Citation: Ramakrishnan VV, Ghaly AE, Brooks MS, Budge SM (2013) Extraction of Proteins from Mackerel Fish Processing Waste Using Alcalase Enzyme. J Bioprocess Biotech 3: 130 doi: 10.4172/2155-9821.1000130

Copyright: () 2013 Ramakrishnan VV, et al. This is an open-access article distributed under the terms of the Creative Commons Attribution License, which permits unrestricted use, distribution, and reproduction in any medium, provided the original author and source are credited. 


\section{Materials and Methods}

\section{Fish samples}

Whole frozen mackerel fish was obtained from Clearwater, Bedford, Nova Scotia, Canada. The mackerel fish waste was obtained from Sea Crest Fisheries, Nova Scotia, Canada. The fish and fish waste were collected in sealed plastic bags and transported to the Biological Engineering Laboratory and stored in a freezer at $-20^{\circ} \mathrm{C}$.

\section{Chemicals and enzymes}

The enzyme alcalase $(\geq 2.4 \mathrm{U} / \mathrm{g})$ used in this study was obtained from Sigma (Catalogue No. P4860, Sigma-Aldrich, Oakville, Ontario, Canada). The chemicals used in the study included: potassium phosphate monobasic, potassium phosphate dibasic, concentrated sulfuric acid, concentrated hydrochloric acid, Bovine serum albumin, copper sulfate, sodium carbonate, sodium tartrate, $2 \mathrm{~N}$ Folin Ciocalteu's Phenol Reagent, trichloroacetic acid and acetone. All the chemicals were obtained from Sigma-Aldrich, Oakville, Ontario, Canada. The reagents used in this study included: $1 \mathrm{~N}$ hydrochloric acid, $6 \mathrm{~N}$ hydrochloric acid, $1 \mathrm{~N}$ sodium hydroxide, $20 \%$ trichloroacetic acid, $1 \mathrm{M}$ potassium phosphate monobasic and $1 \mathrm{M}$ potassium phosphate dibasic. $1 \mathrm{M} \mathrm{pH}$ 8 phosphate buffer was prepared by adding $94.7 \mathrm{ml}$ of $1 \mathrm{M}$ potassium phosphate mono-basic and $5.3 \mathrm{ml}$ of $1 \mathrm{M}$ potassium phosphate dibasic with $100 \mathrm{ml}$ of distilled water.

\section{Experimental procedure}

The enzymatic extraction of protein was carried out according to the procedure described in (Figure 1).The whole mackerel fish was minced in a homogenizer (Model No.4532s/s, Hobart Manufacturing Co. Ltd, Ontario, Canada) without adding water. The minced fish sample (50 g) was first placed in a $500 \mathrm{ml}$ glass bottle and heated in a water bath (Precision 280 Series, Thermo Scientific, Marietta, Ohio, USA) at $90^{\circ} \mathrm{C}$ for $10 \mathrm{~min}$ before the extraction to deactivate the endogenous enzymes. Then, $50 \mathrm{ml}$ of $1 \mathrm{M}$ potassium phosphate buffer ( $\mathrm{pH} 7.5$ ) was added to the fish in the ratio of 1:1 (fish : buffer) and mixed with the mixture using a magnetic stirrer (Corning Magnetic Stirrer PC 210, Thermo Scientific, Marietta, Ohio, USA). The total volume was found to be 100 $\mathrm{ml}$. The $\mathrm{pH}$ of the mixture was measured using a $\mathrm{pH}$ meter (Orion 5 Star $\mathrm{pH}$ meter, Thermo Scientific, Billerica, Massachusetts, USA) and adjusted to 7.5 with $1 \mathrm{~N} \mathrm{NaOH}$. The glass bottle was then placed in a water bath shaker (Precision 2870 Series, Thermo Scientific, Marietta, Ohio, USA) operating at $140 \mathrm{rpm}$ and $55^{\circ} \mathrm{C}$ and kept for $30 \mathrm{~min}$. The temperature was measured using a thermometer (Fisher Scientific, Montreal, Quebec, Canada). The enzymatic hydrolysis was started by adding $0.5 \%$ (by weight of raw material) alcalase. After hydrolyzing the protein for $1 \mathrm{~h}$, the mixture was taken and placed in another water bath (Precision 280 Series, Thermo Scientific, Marietta, Ohio, USA) operating at $90^{\circ} \mathrm{C}$ for $5 \mathrm{~min}$ to inactivate the enzymes.

The mixture was then allowed to cool and centrifuged (Sorvall RT1 Centrifuge, Thermo Scientific, Marietta, Ohio, USA) at $4100 \mathrm{rpm}$ for 40 min. Four layers were formed in the centrifuge tubes: an upper oil layer, a light-lipid layer, a soluble clear protein layer and a bottom sludge layer containing the remaining fish tissues (Figure 2). The upper oil layer was carefully removed using a pipette. The soluble protein layer and the lipid layer were removed by tilting the centrifuge tubes and pouring the material into a filtration funnel without disturbing the sludge. The remaining sludge layer was discarded. The protein hydrolysate was obtained by filtering out the lipid layer from the liquid protein using Fisher P5 filter paper (Catalogue No. S47571C, Fisher Scientific, Montreal, Quebec, Canada). The protein hydrolysate was first analyzed using Lowry method. Then, the filtered protein was spray dried using a spray dryer (Mini Pulvis Spray GS-310, Yamato Scientific America, Santa Clara, California, USA) at an inlet temperature of $130^{\circ} \mathrm{C}$, outlet temperature of $90^{\circ} \mathrm{C}$ and flow rate of $1-2 \mathrm{ml} / \mathrm{min}$. The spray dried protein was stored at $-20^{\circ} \mathrm{C}$ until used for yield determination.

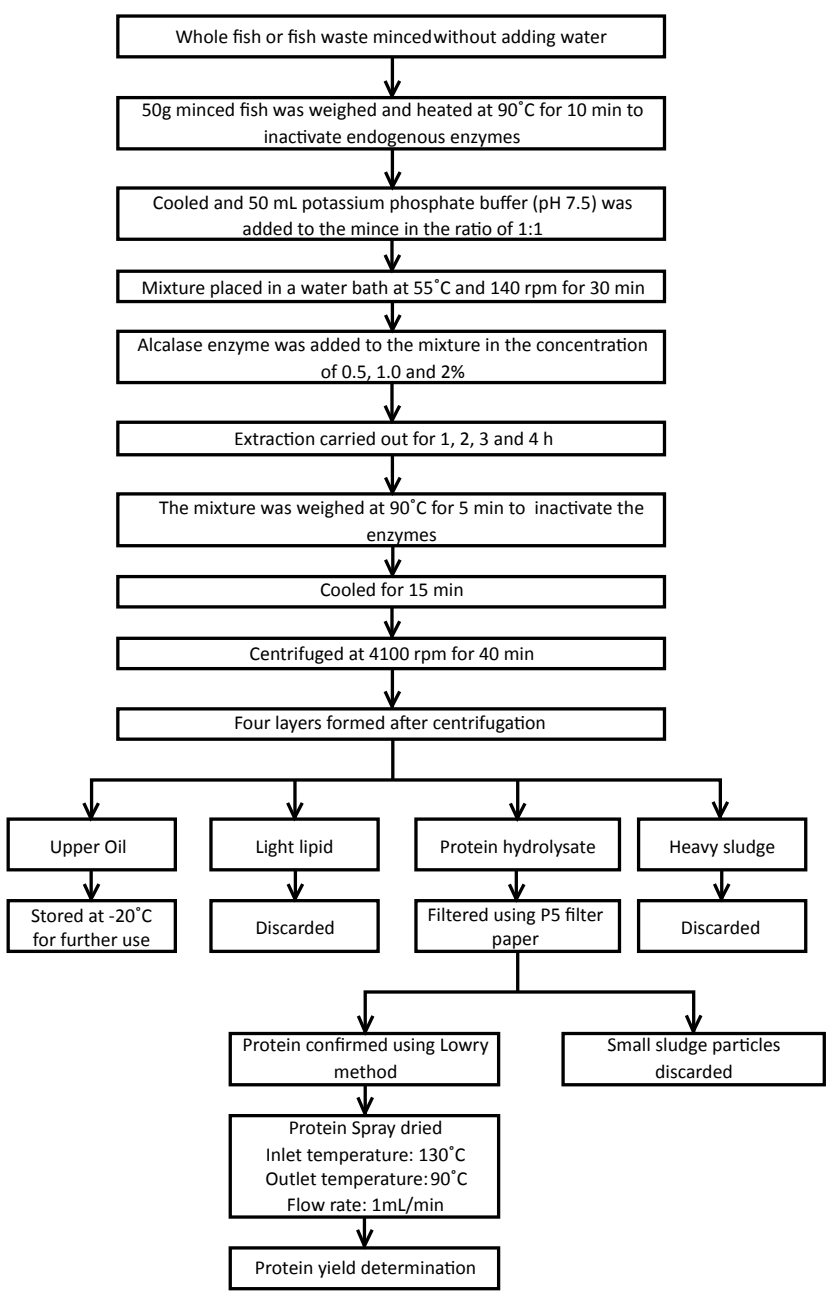

Figure 1: Enzymatic extraction of protein from whole fish.

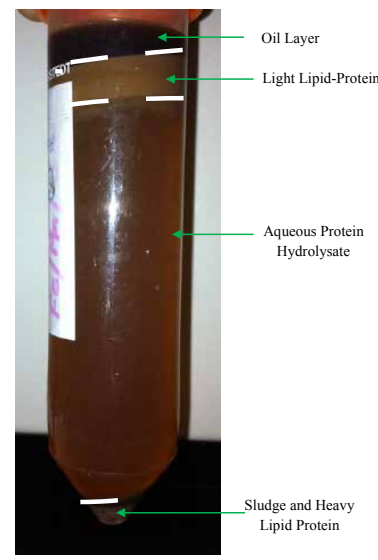

Figure 2: Four layers when recovering soluble fish protein hydrolysate. 
The enzymatic hydrolysis of proteins from the various parts of mackerel fish (head, frames and fins, tails, gut and skin together) was carried out using the same procedure. The same procedure was also repeated with all reaction times and enzyme concentrations.

\section{Chemical analyses}

The moisture content was analyzed by the oven drying method, the fat content was analyzed using the chloroform/methanol method of lipid extraction, the protein content was analyzed using the Kjeldhal method, the ash content was analyzed using the standard ASTM E175501 and the carbohydrate content was analyzed using the standard ASTM D5896-96 in the fish samples. These analyses were performed by Nova West Laboratory Ltd., Saulnierville, Nova Scotia, Canada.

\section{Determination of protein}

The protein concentration was determined by the Lowry method according to the procedure described by Gerhardt et al. [17]. In this procedure, the proteins were first pretreated with copper ions in an alkali solution. The aromatic amino acids in the treated sample reduced the phosphomolybdic-phosphotungstic acid present in the Folin reagent. Since the endpoint of the reaction has a blue color, the amount of protein in the sample could be estimated by reading the absorbance using a spectrophotometer (Genesys 10 S UV-VIS spectrophometer, Thermo Scientific, Ohio, USA) at $750 \mathrm{~nm}$.

Solution A was prepared by mixing $2.8598 \mathrm{~g} \mathrm{NaOH}$ and $14.3084 \mathrm{~g}$ $\mathrm{Na}_{2} \mathrm{CO}_{3}$ in $500 \mathrm{ml}$ distilled water in a volumetric flask. Solution B was made by adding $1.4232 \mathrm{~g} \mathrm{CuSO}_{4} .5 \mathrm{H}_{2} \mathrm{O}$ to $100 \mathrm{ml}$ distilled water in a volumetric flask. Solution $\mathrm{C}$ was prepared by adding $2.85299 \mathrm{~g}$ sodium tartarate to $100 \mathrm{ml}$ water in a volumetric flask. Lowry solution was prepared fresh daily by combining solutions $\mathrm{A}+\mathrm{B}+\mathrm{C}$ together in the ratio 100:1:1. Folin Reagent was prepared fresh by adding $5 \mathrm{ml}$ of $2 \mathrm{~N}$ Folin Ciocalteu's Phenol Reagent to $6 \mathrm{ml}$ distilled water. Bovine serum albumin (BSA) was used as the standard protein solution.

Several concentrations were prepared for the standard curve. $0.05 \mathrm{~g}$ of BSA was added to a $500 \mathrm{ml}$ volumetric flask containing distilled water. The final concentration of the BSA solution was $100 \mathrm{mg} / \mathrm{l}$. Dilutions ranging from 0 to $100 \mathrm{mg} / \mathrm{L}$ were prepared. The absorbance values of the BSA standards were plotted against the BSA concentrations as shown in (Figure 3).

The percentage of protein recovery from the fish was defined as the ratio of protein yield obtained during the extraction process by spray drying to the amount of protein estimated Kjeldhal protein multiplied

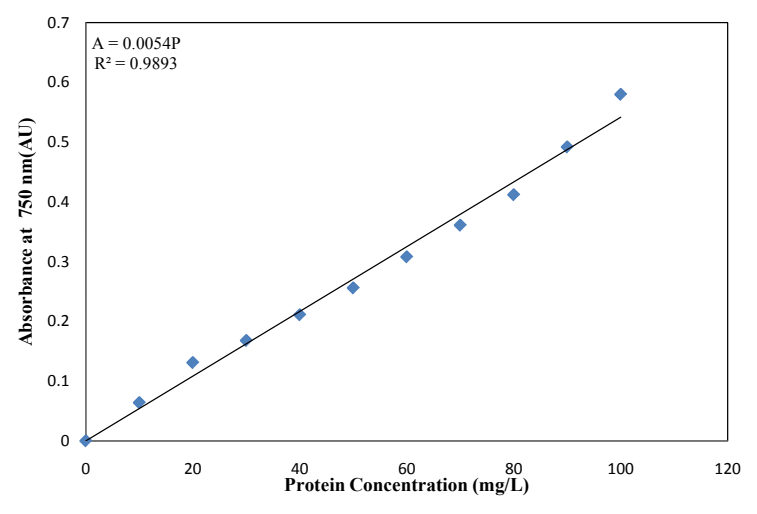

Figure 3: Standard curve for protein concentration. by 100 and was calculated as follows:

Percent Protein Recovery $(\%)=\frac{\text { Recovered protein }(\%)}{\text { Kjeldhalprotein }(\%)} \times 100$

The total protein yield from the fish was defined as the concentration of protein in the raw material multiplied by the average weight of part and was calculated as follows:

Total Protein Yield $(g)=\frac{\text { Recovered protein }(g)}{\text { Weight of raw material }(g)} \times$ Average weight of fish part $(g)(2)$ Statistical analyses

Statistical analyses were performed on protein and oil results using Minitab Statistics Software (Version 16.2.2, Minitab Inc., Canada). Both analysis of variance (ANOVA) and Tukey's grouping were carried out.

\section{Results}

\section{Weight distribution and nutritional composition}

The average weight of a whole fish was $487.11 \mathrm{~g}$. The weight distribution of the different parts of the fish is shown in (Table 1). The flesh, head, frame, fins and tails, skin and gut make up $286.91 \mathrm{~g}(58.90 \%)$, $75.87 \mathrm{~g}(15.58 \%), 37.12 \mathrm{~g}(7.62 \%), 5.71 \mathrm{~g}(1.17 \%), 34.74 \mathrm{~g}(7.13 \%)$, and $36.69 \mathrm{~g}$ (7.53\%), respectively. About $3.26 \%$ of fish tissue was lost during the cutting of fish and preparing the samples.

The nutritional composition (moisture, protein fat, carbohydrate and ash contents) of whole fish and fish parts are shown in (Table 2).The average protein, fat, carbohydrate and ash contents were 15.57, 16.52, 0.65 and $1.68 \%$ for the whole fish, $12.30,17.16,1.17$ and $3.74 \%$ for the head, $14.16,10.43,0.31$ and $3.48 \%$ for the frame and $12.18,20.84,0.00$ and $1.36 \%$ for the fins, tails, skin and gut, respectively. The whole fish had the highest protein content $(15.57 \%)$ while the fins, tails, skin and gut had the highest fat content (20.84\%) and the head had the highest carbohydrate content $(1.17 \%)$.

\section{Protein yield}

Fish protein was extracted from the whole fish (WF), head $(\mathrm{H})$, frames (F) and fin, tail, skin and gut (FTSG). The extraction was carried out using three enzyme concentrations $(0.5,1.0$, or $2.0 \%)$ and four reaction times $(1,2,3$ and $4 \mathrm{~h})$. After extraction, the fish protein hydrolysate was obtained by centrifugation and then spray dried to obtain dried protein powder. The protein powder was weighed and the amount of protein recovered (yield) from each sample was calculated. The results are shown in Table 3 .

Analysis of variance (ANOVA) and Tukey's grouping were performed on the protein yield data as shown in Tables 4 and 5. The effects of fish parts, enzyme concentration and hydrolysis time were significant at the 0.001 level. There were significant interactions among the various parameters at the 0.001 level. The results obtained from the Tukey's grouping indicated that head and frame were not significantly different from each other but were significantly different from the whole fish (WF) and fin, tail, skin and guts (FTSG) at the 0.05 level. The highest protein yield $(61.02 \%)$ was obtained from the frame (F). The three, enzyme concentrations $(0.5,1.0$ and $2.0 \%)$ were significantly different from each other at the 0.05 level. The highest protein yield $(65.30 \%)$ was achieved at the $2 \%$ enzyme concentration.

\section{Effect of enzyme concentration on protein yield}

The effect of enzyme concentrations $(0.5,1$ and $2 \%)$ at different hydrolysis times $(1,2,3$ and $4 \mathrm{~h})$ on the protein yield from different parts are shown in Figure 4. The results indicated that increasing enzyme concentration from 0.5 to $2 \%$ increased the protein yield for all fish parts. 
Citation: Ramakrishnan VV, Ghaly AE, Brooks MS, Budge SM (2013) Extraction of Proteins from Mackerel Fish Processing Waste Using Alcalase Enzyme. J Bioprocess Biotech 3: 130 doi: 10.4172/2155-9821.1000130

Page 4 of 9

\begin{tabular}{|c|c|c|c|c|c|c|c|c|c|}
\hline Sample & Whole (g) & Flesh (g) & Waste (g) & Head (g) & Frames $(\mathbf{g})$ & Fins \& Tails (g) & Skin (g) & Gut (g) & Loss (g) \\
\hline 1 & 470.03 & 256.41 & 213.62 & 82.23 & 41.87 & 7.62 & 31.51 & 38.53 & 11.86 \\
\hline 2 & 403.18 & 213.20 & 189.98 & 66.34 & 19.48 & 3.67 & 41.96 & 32.73 & 25.80 \\
\hline 3 & 514.74 & 302.63 & 212.11 & 79.41 & 38.71 & 9.73 & 32.43 & 32.18 & 19.65 \\
\hline 4 & 492.58 & 301.65 & 190.93 & 81.70 & 26.58 & 5.32 & 38.08 & 39.25 & 0.00 \\
\hline 5 & 366.48 & 187.79 & 178.69 & 63.57 & 36.66 & 4.77 & 30.73 & 31.17 & 11.79 \\
\hline 6 & 580.41 & 340.69 & 239.72 & 85.73 & 53.06 & 6.07 & 30.30 & 53.12 & 11.44 \\
\hline 7 & 438.25 & 246.08 & 192.17 & 65.76 & 30.79 & 3.42 & 38.26 & 32.3 & 21.64 \\
\hline 8 & 557.25 & 343.86 & 213.39 & 80.94 & 34.05 & 6.23 & 30.95 & 32.3 & 28.92 \\
\hline 9 & 529.35 & 313.98 & 215.37 & 73.57 & 52.96 & 4.79 & 38.17 & 37.85 & 8.03 \\
\hline 10 & 518.85 & 302.85 & 216.00 & 79.49 & 38.96 & 5.5 & 35.01 & 37.52 & 19.52 \\
\hline Average & $487.11 \pm 67.89$ & $286.91 \pm 52.79$ & $206.20 \pm 17.93$ & $75.87 \pm 7.97$ & $37.31 \pm 10.56$ & $5.71 \pm 1.87$ & $34.74 \pm 4.12$ & $36.69 \pm 7.53$ & $15.87 \pm 8.79$ \\
\hline Percentage & 100.00 & 57.67 & 42.33 & 15.58 & 7.66 & 1.17 & 7.13 & 7.53 & 3.26 \\
\hline
\end{tabular}

Table 1: Weight distribution of mackerel fish parts.

\begin{tabular}{|l|l|l|l|l|l|}
\hline \multicolumn{1}{|c|}{ Sample } & \multicolumn{1}{c|}{ Moisture (\%) } & \multicolumn{1}{c|}{ Protein (\%) } & Fat (\%) & \\
\hline Head & 65.63 & 12.30 & 17.16 & 1.17 \\
\hline Frames & 71.62 & 14.16 & 10.43 & 0.31 \\
\hline Fins, Tails, Skin and Gut & 65.62 & 12.18 & 20.84 & 3.74 \\
\hline Whole Fish & 65.58 & 15.57 & 16.52 & 0.00 \\
\hline
\end{tabular}

Table 2: Nutritional composition of mackerel fish and fish waste.

\begin{tabular}{|c|c|c|c|c|c|c|c|c|c|}
\hline \multirow{3}{*}{$\begin{array}{l}\text { Enzyme Concentration } \\
(\%)\end{array}$} & \multirow{3}{*}{$\begin{array}{l}\text { Hydrolysis } \\
\text { Time (h) }\end{array}$} & \multicolumn{8}{|c|}{ Protein Yield } \\
\hline & & \multicolumn{2}{|c|}{ Whole Fish } & \multicolumn{2}{|c|}{ Head } & \multicolumn{2}{|c|}{ Frame } & \multicolumn{2}{|c|}{ FTSG } \\
\hline & & (g) & $(\%)$ & (g) & $(\%)$ & (g) & $(\%)$ & (g) & $(\%)$ \\
\hline \multirow{4}{*}{0.5} & 1 & $3.53 \pm 0.15$ & 7.06 & $3.28 \pm 0.03$ & 6.56 & $3.52 \pm 0.11$ & 7.04 & $2.48 \pm 0.06$ & 4.96 \\
\hline & 2 & $3.86 \pm 0.12$ & 7.72 & $3.55 \pm 0.02$ & 7.10 & $3.97 \pm 0.01$ & 7.94 & $2.75 \pm 0.04$ & 5.50 \\
\hline & 3 & $4.53 \pm 0.11$ & 9.06 & $3.75 \pm 0.04$ & 7.50 & $4.19 \pm 0.02$ & 8.38 & $2.95 \pm 0.03$ & 5.90 \\
\hline & 4 & $5.21 \pm 0.01$ & 10.42 & $3.82 \pm 0.02$ & 7.64 & $4.39 \pm 0.03$ & 8.78 & $3.28 \pm 0.02$ & 6.56 \\
\hline \multirow{4}{*}{1} & 1 & $3.67 \pm 0.03$ & 7.34 & $3.22 \pm 0.02$ & 6.44 & $3.81 \pm 0.04$ & 7.62 & $2.96 \pm 0.02$ & 5.92 \\
\hline & 2 & $4.17 \pm 0.10$ & 8.34 & $3.53 \pm 0.02$ & 7.06 & $4.25 \pm 0.02$ & 8.50 & $3.37 \pm 0.05$ & 6.74 \\
\hline & 3 & $5.14 \pm 0.12$ & 10.28 & $3.75 \pm 0.02$ & 7.50 & $4.46 \pm 0.02$ & 8.92 & $3.58 \pm 0.04$ & 7.16 \\
\hline & 4 & $5.54 \pm 0.01$ & 11.08 & $3.92 \pm 0.03$ & 7.84 & $4.68 \pm 0.02$ & 9.36 & $3.78 \pm 0.02$ & 7.56 \\
\hline \multirow{4}{*}{2} & 1 & $4.24 \pm 0.11$ & 8.48 & $3.39 \pm 0.02$ & 6.78 & $3.63 \pm 0.02$ & 7.26 & $3.45 \pm 0.04$ & 6.90 \\
\hline & 2 & $4.86 \pm 0.05$ & 9.72 & $4.00 \pm 0.09$ & 8.00 & $4.71 \pm 0.03$ & 9.42 & $3.95 \pm 0.03$ & 7.90 \\
\hline & 3 & $5.44 \pm 0.02$ & 10.88 & $4.22 \pm 0.02$ & 8.44 & $4.97 \pm 0.05$ & 9.94 & $4.14 \pm 0.02$ & 8.28 \\
\hline & 4 & $5.94 \pm 0.02$ & 11.88 & $4.36 \pm 0.03$ & 8.72 & $5.28 \pm 0.02$ & 10.56 & $4.26 \pm 0.02$ & 8.52 \\
\hline
\end{tabular}

Sample size $=50 \mathrm{~g}$

Whole fish $=7.78 \%(15.57 \%)$

Head $=6.15 \%(12.30 \%)$

Frame $=7.08 \%(14.16 \%)$ and

Fin, tail, skin and gut $(\mathrm{FTSG})=6.09 \%(12.18 \%)$

Table 3: Protein yield.

For the $0.5 \%$ enzyme concentration and $1 \mathrm{~h}$ hydrolysis time, the protein yield was $45.34,53.39,49.67$ and $40.78 \%$ for the whole fish (WF), head $(\mathrm{H})$, frame (F) and fin, tail, skin and guts (FTSG), respectively. When the enzyme concentration was increased from 0.5 to $1 \%$, the protein yield increased from 45.34 to $47.18 \%$ (4.06\%), from 40.78 to $48.60 \%(19.19 \%)$ and from 49.67 to $53.86 \%$ (8.43\%) for the whole fish (WF), fin, tail, skin and guts (FTSG) and frame (F), respectively and decreased from 53.39 to $52.41 \%$ (1.83\%) for head $(\mathrm{H})$. However, when the enzyme concentration was further increased from 1 to $2 \%$, the protein yield decreased from 53.86 to $51.22 \%$ (4.89\%) for frame (F), and increased from 47.18 to $54.46 \%$ (15.42\%), from 48.60 to $56.70 \%$ (16.66\%), from 52.41 to $55.18 \%$ (3.29\%), from whole fish (WF), fin, tail, skin and guts (FTSG) and head (H), respectively. Similar trends were observed with other hydrolysis times (2, 3 and $4 \mathrm{~h})$. The decrease in the yield for the head $(\mathrm{H})$ is because the low enzyme concentration of $0.5 \%$ enzyme concentration and the small hydrolysis time of $1 \mathrm{~h}$ were not enough to release all the protein into the system.

\section{Effect of hydrolysis time on protein yield}

The effect of hydrolysis time (1, 2, 3 and $4 \mathrm{~h})$ on the protein yield at different enzyme concentrations $(0.5,1$ and $2 \%)$ is shown in Figure 5.The results indicated that increasing hydrolysis time from 1 to $4 \mathrm{~h}$ increased the protein yield from the different parts of fish. There was no protein yield observed at zero time from any of the fish parts. However, there was a significant increase in the protein yield from all fish parts during the first hour.

For the $0.5 \%$ enzyme concentration, an increase in the hydrolysis times from 1 to $4 \mathrm{~h}$, increased the protein yield from 45.34 to $66.92 \%$ (47.59\%), from 40.78 to $53.80 \%$ (31.94\%), from 53.39 to $62.17 \%$ (16.44\%) and from 49.67 to $61.96 \%$ (24.73\%) for the whole fish (WF), fin, tail, skin and gut (FTSG), head (H) and frame (F) increased, respectively. Similar trends were observed at the other enzyme concentrations. Increases of 50.82, 27.59, 21.71 and $22.64 \%$ and 40.09, 23.36, 28.39 and $45.50 \%$ with the $1 \%$ and $2 \%$ enzyme concentrations were observed for 


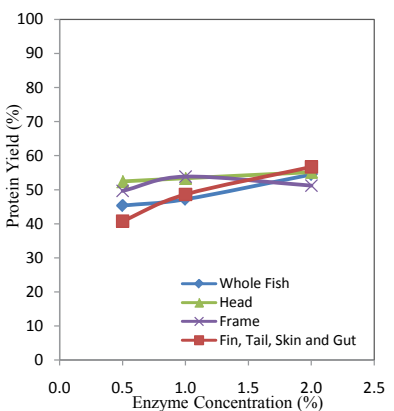

(a) $1 \mathrm{~h}$

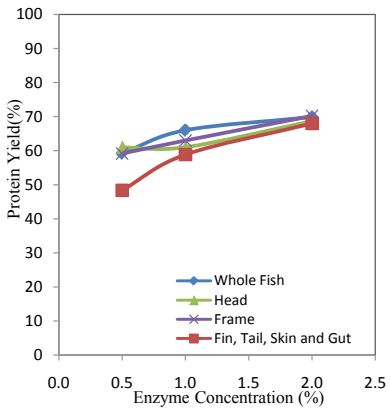

(c) $3 \mathrm{~h}$

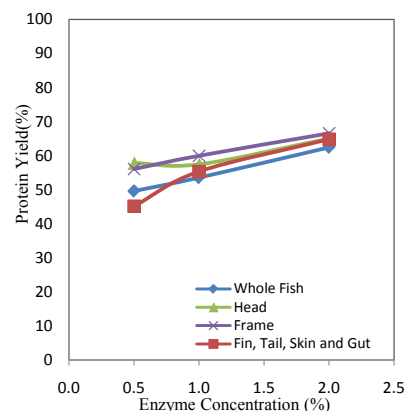

(b) $2 \mathrm{~h}$

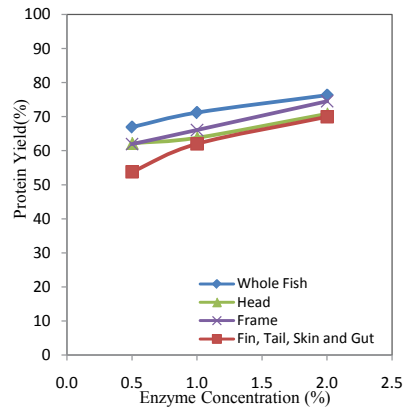

(d) $4 \mathrm{~h}$
Figure 4: Effect of enzyme concentrations on protein yield from different fish parts at different reaction times.

\begin{tabular}{|c|c|c|c|c|c|}
\hline Source & DF & SS & MS & $\mathrm{F}$ & $\mathrm{P}$ \\
\hline Total & 143 & 9836.37 & & & \\
\hline \multicolumn{6}{|l|}{ Model } \\
\hline Parts & 3 & 587.33 & 195.78 & 395.34 & 0.001 \\
\hline EC & 2 & 2888.51 & 1444.26 & 2916.43 & 0.001 \\
\hline HT & 3 & 5083.29 & 1694.43 & 3421.61 & 0.001 \\
\hline Parts*EC & 6 & 486.24 & 81.04 & 163.65 & 0.001 \\
\hline Parts*HT & 9 & 486.34 & 54.04 & 109.12 & 0.001 \\
\hline EC*HT & 6 & 128.11 & 21.35 & 43.12 & 0.001 \\
\hline Parts ${ }^{*} E C^{*} H T$ & 18 & 129.00 & 7.17 & 14.47 & 0.001 \\
\hline Error & 96 & 47.54 & 0.50 & & \\
\hline
\end{tabular}

DF $=$ Degree of freedom

SS $=$ Sum of square

MS =Mean of square

$\mathrm{EC}=$ Enzyme concentration

$\mathrm{HT}=$ Hydrolysis time

$\mathrm{R}^{2}=99.52$

$\mathrm{CV}=13.94 \%$

Table 4: Analysis of variance for protein yield

whole fish (WF), fin, tail, skin and gut (FTSG), head (H) and frame (F), respectively.

\section{Total protein recovery}

The total protein recovered from various fish parts is shown in (Table 6). The results indicated the highest amount of protein was recovered from whole fish (WF), followed by the head (H) and fin, tail, skin and gut (FTSG) and the lowest amount of protein was recovered from the frame $(\mathrm{F})$.

\section{Discussion}

The selection of enzyme plays an important role in the extraction of proteins from fish and fish waste. Several researchers [9,10,18-20] reported that alcalase was the best enzyme for the extraction of proteins from fish and fish waste. Kristinsson and Rasco [9] stated that alcalase is prominently used in the hydrolysis of proteins from fish due to its high degree of hydrolysis in a relatively short time.

In this study, the enzymatic hydrolysis of the whole fish and fish waste (head, frame, fin, tail, skin and gut) was carried out with the enzyme alcalase to obtain protein for further use as a substrate for production of amino acids. The extraction process of protein was carried out at $55^{\circ} \mathrm{C}$ which is the optimum temperature for alcalase as reported by several authors [12,19-22]. The effects of enzyme concentration $(0.5$, 1 or $2 \%)$ and hydrolysis time (1, 2, 3 and $4 \mathrm{~h}$ ) were investigated in order to determine the protein yield from whole fish and various fish parts. The highest protein yield from whole fish (WF), head $(\mathrm{H})$, frame $(\mathrm{F})$

\begin{tabular}{|l|l|l|l|l|}
\hline \multicolumn{1}{|c|}{ Factors } & \multicolumn{1}{|c|}{ Level } & \multicolumn{1}{c|}{ N } & Mean Yield (\%) & Tukey Grouping \\
\hline \multirow{4}{*}{ Parts } & Whole fish & 36 & 60.17 & A \\
\hline & Head & 36 & 60.73 & B \\
\hline & Frame & 36 & 61.02 & B \\
\hline & FTSG & 36 & 56.03 & C \\
\hline \multirow{2}{*}{$\begin{array}{l}\text { Enzyme Concentration } \\
\text { (\%) }\end{array}$} & 0.5 & 48 & 54.40 & A \\
\hline & 1.0 & 48 & 58.76 & B \\
\hline \multirow{3}{*}{ Hydrolysis time (h) } & 2.0 & 48 & 65.30 & C \\
\hline & 1 & 36 & 50.73 & A \\
\hline & 2 & 36 & 57.81 & B \\
\hline & 3 & 36 & 62.78 & C \\
\hline
\end{tabular}

Groups with the same letter are not significantly different from each other at the 0.05 level.

FTSG $=$ Fin, tail, skin and gut

Table 5: Tukey's grouping on protein yield.
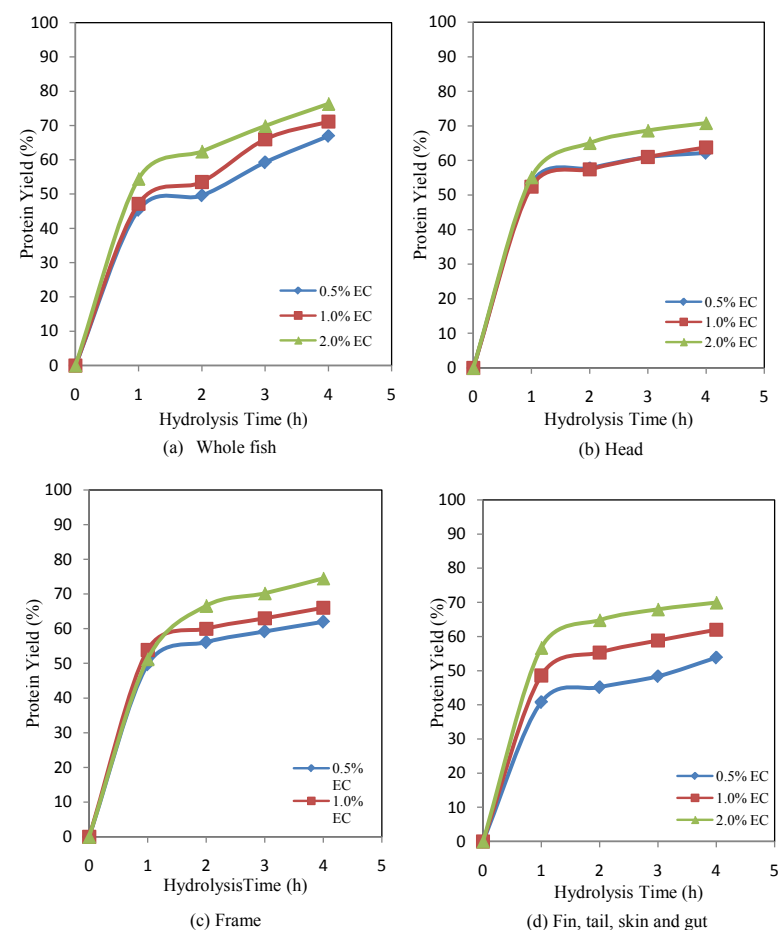

Figure 5: Effect of hydrolysis time on protein yield from different fish parts at different enzyme concentrations. 


\begin{tabular}{|c|c|c|c|c|c|c|c|c|c|}
\hline \multirow{2}{*}{$\begin{array}{c}\text { Enzyme } \\
\text { Concentration (\%) }\end{array}$} & \multirow{2}{*}{$\begin{array}{c}\text { Hydrolysis } \\
\text { Time (h) }\end{array}$} & \multicolumn{2}{|c|}{ Whole Fish } & \multicolumn{2}{|r|}{ Head } & \multicolumn{2}{|c|}{ Frame } & \multicolumn{2}{|c|}{ FTSG } \\
\hline & & $\begin{array}{l}\text { Protein } \\
\text { Yield (g) }\end{array}$ & $\begin{array}{l}\text { Total Protein } \\
\text { (g) }\end{array}$ & $\begin{array}{l}\text { Protein } \\
\text { Yield (g) }\end{array}$ & $\begin{array}{l}\text { Total Protein } \\
\text { (g) }\end{array}$ & $\begin{array}{l}\text { Protein } \\
\text { Yield (g) }\end{array}$ & $\begin{array}{c}\text { Total Protein } \\
\text { (g) }\end{array}$ & $\begin{array}{l}\text { Protein } \\
\text { Yield (g) }\end{array}$ & Total Protein $(\mathbf{g})$ \\
\hline \multirow{4}{*}{0.5} & 1 & $3.53 \pm 0.15$ & 34.39 & $3.28 \pm 0.03$ & 4.98 & $3.52 \pm 0.11$ & 2.61 & $2.48 \pm 0.06$ & 3.83 \\
\hline & 2 & $3.86 \pm 0.12$ & 37.60 & $3.55 \pm 0.02$ & 5.39 & $3.97 \pm 0.01$ & 2.95 & $2.75 \pm 0.04$ & 4.24 \\
\hline & 3 & $4.53 \pm 0.11$ & 44.13 & $3.75 \pm 0.04$ & 5.69 & $4.19 \pm 0.02$ & 3.11 & $2.95 \pm 0.03$ & 4.55 \\
\hline & 4 & $5.21 \pm 0.01$ & 50.76 & $3.82 \pm 0.02$ & 5.80 & $4.39 \pm 0.03$ & 3.26 & $3.28 \pm 0.02$ & 5.06 \\
\hline \multirow{4}{*}{1.0} & 1 & $3.67 \pm 0.03$ & 35.75 & $3.22 \pm 0.02$ & 4.89 & $3.81 \pm 0.04$ & 2.83 & $2.96 \pm 0.02$ & 4.57 \\
\hline & 2 & $4.17 \pm 0.10$ & 40.62 & $3.53 \pm 0.02$ & 5.36 & $4.25 \pm 0.02$ & 3.16 & $3.37 \pm 0.05$ & 5.20 \\
\hline & 3 & $5.14 \pm 0.12$ & 50.07 & $3.75 \pm 0.02$ & 5.69 & $4.46 \pm 0.02$ & 3.31 & $3.58 \pm 0.04$ & 5.52 \\
\hline & 4 & $5.54 \pm 0.01$ & 53.97 & $3.92 \pm 0.03$ & 5.95 & $4.68 \pm 0.02$ & 3.47 & $3.78 \pm 0.02$ & 5.83 \\
\hline \multirow{4}{*}{2.0} & 1 & $4.24 \pm 0.11$ & 41.31 & $3.39 \pm 0.02$ & 5.14 & $3.63 \pm 0.02$ & 2.69 & $3.45 \pm 0.04$ & 5.32 \\
\hline & 2 & $4.86 \pm 0.05$ & 47.35 & $4.00 \pm 0.09$ & 6.07 & $4.71 \pm 0.03$ & 3.50 & $3.95 \pm 0.03$ & 6.09 \\
\hline & 3 & $5.44 \pm 0.02$ & 53.00 & $4.22 \pm 0.02$ & 6.40 & $4.97 \pm 0.05$ & 3.69 & $4.14 \pm 0.02$ & 6.39 \\
\hline & 4 & $5.94 \pm 0.02$ & 57.87 & $4.36 \pm 0.03$ & 6.62 & $5.28 \pm 0.02$ & 3.92 & $4.26 \pm 0.02$ & 6.57 \\
\hline
\end{tabular}

Whole Fish $=487.11 \mathrm{~g}$

Head $=75.87 \mathrm{~g}$;

Frame $=37.12 \mathrm{~g}$

Fin Tail Skin and Gut (FTSG) $=77.14 \mathrm{~g}$

Table 6: Total protein recovered from fish parts

and fin, tail, skin and gut (FTSG) after $4 \mathrm{~h}$ of hydrolysis using a $2 \%$ enzyme concentration was $76.30,70.84,74.53$ and $69.95 \%$, respectively. The enzyme concentration and the reaction time had significant effects on the protein yield.

\section{Enzyme concentration}

In this study, the enzyme concentration was kept below $2 \%$. The results showed that when the enzyme concentration was increased from 0.5 to $1 \%$, while using $1 \mathrm{~h}$ hydrolysis time, the increases in protein yield were $4.06,1.82,8.43$ and $19.19 \%$. When the enzyme concentration was further increased from 1 to $2 \%$ using the same hydrolysis time, additional increases in protein yields of 15.42, 5.27, 4.89 and $16.16 \%$ were obtained from the whole fish $(\mathrm{WF})$, head $(\mathrm{H})$, frame $(\mathrm{F})$ and fin, tail, skin and gut (FTSG), respectively. Similar trends were seen with other hydrolysis times for all fish parts. The increase in enzyme concentration (from 0.5 to $2 \%$ ) increased the protein yield because more enzyme molecules became associated with fish particles thus releasing more protein molecules into the system $[9,19]$. Benjakul and Morrissey [23] obtained similar results and indicated that the increase in the alcalase enzyme concentration increased the overall proteolysis rate and the solubilization of protein. Tello et al., Marquez and Vazquez and Moreno and Cuadrado [24-26] reported similar results from kinetic studies involving the hydrolysis of whey-proteins, bovine hemoglobin and vegetable proteins, respectively.

Shahidi et al. [19] reported that during the initial phase of hydrolysis, bulk soluble proteins were released and no increase in the release of soluble hydrolysates was seen when additional enzyme was added to the system during the stationary phase of the hydrolysis. This may be due to the product inhibition present during the hydrolysis or due to total cleavage of all the susceptible peptide bonds. The authors also suggested that removal of products during the hydrolysis can improve the rate and the recovery of proteins.

Gildberg [6] reported that an increase in the enzyme concentration increased the rate of reaction. The author suggested that the fish tissues are very complex substrates and contain a large amount of proteinase inhibitors which makes it difficult to explain the hydrolysis process. Kristinsson and Rasco [9] stated that kinetics of the fish protein hydrolysis process is complicated due to the presence of various types of peptide bonds present and their specificity for the attack by enzymes during the process. Diniz and Martin [21] reported that once all the substrates present in the system are attached to the active sites of enzyme, there will be free enzymes which may inhibit the hydrolysis process and may even hydrolyze it. Therefore, increasing the enzyme concentration above $4 \%$ is not recommended and would not be cost effective.

The results obtained from the present study showed that increasing the enzyme concentration by $400 \%$ (from 0.5 to $2 \%$ ) increased the protein yield by of $3.13-43.52 \%$ depending upon the fish part and reaction time used as shown in (Table 7). Increasing the enzyme concentration for a small increase in protein yield seems unjustified. Therefore, the concentration of $0.5 \%$ should be used for the protein extraction unless the enzyme is reused or an immobilized reactor is used in order to reduce the cost associated with the enzyme.

\section{Hydrolysis time}

Generally, increasing the hydrolysis time from 0.5 to $2 \%$ increased protein yield. All the hydrolytic curves obtained at different enzyme concentrations $(0.5,1$ and $2 \%)$ and different times $(1,2,3$ and $4 \mathrm{~h})$ tend to have an initial rapid phase during the first $1 \mathrm{~h}$ followed by a phase of slow increase after the core proteins have been hydrolyzed (amount of substrate in the system is decreased). Even though the protein yield slowly increased after the first hour till the end of the fourth hour, the rate of increases in protein yield started to decrease for all enzyme concentrations and all fish parts. The decrease in the rate was due to the decrease in the substrate concentration.

Shahidi et al., Guerard et al. and Gbogouri et al. [19,22,10] reported on hydrolysis studies in which hydrolysis time ranging from 1 to $5 \mathrm{~h}$ were used and observed similar trends. Guerard et al. [20] reported that increasing the time above $5.5 \mathrm{~h}$ did not cause any insignificant increase in the protein yield and stopped the hydrolysis process after $4 \mathrm{~h}$.

Liaset et al. [27] reported that during the enzymatic hydrolysis of cod using pepsin, alcalase and Neutrase, the reaction mechanism followed two first order kinetics processes, in which the first process involves an initial fast reaction in which loosely bound polypeptide chains were cleaved to form insoluble protein particles and in the second process the compact proteins were digested. The author also suggested that this mechanism of slow reaction at the end may be due to decrease in enzyme activity, substrate saturation or product inhibition. 


\begin{tabular}{|l|l|l|}
\hline \multicolumn{1}{|c|}{ Parts } & \multicolumn{1}{c|}{ Time (h) } & \multicolumn{1}{c|}{$\begin{array}{c}\text { Increase in } \\
\text { Protein Yield (\%) }\end{array}$} \\
\hline \multirow{3}{*}{ Whole fish } & 1 & 20.11 \\
\hline \multirow{3}{*}{ Head } & 2 & 25.91 \\
\hline \multirow{3}{*}{ Frame } & 4 & 18.00 \\
\hline & 1 & 14.01 \\
\hline \multirow{3}{*}{ Fins, Tail, Skin and Gut } & 2 & 3.35 \\
\hline & 3 & 12.57 \\
\hline & 4 & 12.62 \\
\hline & 1 & 13.95 \\
\hline & 2 & 3.13 \\
\hline & 3 & 18.72 \\
\hline & 4 & 18.62 \\
\hline & 4 & 20.29 \\
\hline
\end{tabular}

Table 7: The increase in protein yield as a result of increase in enzyme concentration from 0.5 to $2 \%$.

\begin{tabular}{|l|l|l|}
\hline \multicolumn{1}{|c|}{ Parts } & \multicolumn{1}{|c|}{$\begin{array}{c}\text { Enzyme concentration } \\
\text { (\%) }\end{array}$} & $\begin{array}{c}\text { Increase in } \\
\text { Protein Yield (\%) }\end{array}$ \\
\hline \multirow{3}{*}{ Whole Fish } & 0.5 & 47.59 \\
\hline \multirow{3}{*}{ Head } & 1.0 & 50.82 \\
\hline \multirow{3}{*}{ Frame } & 2.0 & 40.09 \\
\hline \multirow{3}{*}{ Fins, Tail, Skin and Gut } & 0.5 & 16.45 \\
\hline & 1.0 & 21.72 \\
\hline & 2.0 & 28.39 \\
\hline & 0.5 & 22.64 \\
\hline & 1.0 & 24.74 \\
\hline & 2.0 & 45.50 \\
\hline & 0.5 & 31.95 \\
\hline
\end{tabular}

Table 8: The increase in protein yield as a result of increase in reaction time from 1 to $4 \mathrm{~h}$.

\begin{tabular}{|l|l|}
\hline Parameters & Optimum Level \\
\hline Enzyme & alcalase \\
\hline Enzyme concentration & $0.5 \%$ \\
\hline Reaction Time & $1 \mathrm{~h}$ \\
\hline $\mathrm{pH}$ & 7.5 \\
\hline Temperature & $55^{\circ} \mathrm{C}$ \\
\hline
\end{tabular}

Table 9: Effective parameters for protein extraction from fish and fish waste.

Gbogouri et al. [10] observed same phenomenon when using alcalase to extract proteins from salmon byproducts. Guerard et al. [22] compared umamizyme with alcalase during hydrolysis of tuna waste and observed a decrease of the hydrolysis rates suggesting enzyme deactivation or enzyme inhibition.

Guerard et al. [22] reported that protein proteolysis can happen sequentially, releasing one peptide at a time (one by one mechanism) or by forming intermediates that are further hydrolyzed as the time progresses (zipper mechanism). In this study, during the hydrolysis of fish, there was rapid burst phase of reaction followed by a steady phase till the end of the experiment indicating that the enzymatic reaction followed the zipper mechanism. Guerard et al. [20] reported that in the presence of sufficient substrate, the initial rate of reaction increased linearly when the enzyme concentration was increased up to $3 \%$, after which the reaction followed the zipper mechanism as it depended upon the reaction time during the extraction process.

Choisnard et al. [28] reported that during pepsin hydrolysis of protein, one molecule of pepsin cleaved the protein substrate once and then dissociated from it following one-by-one mechanism. In another case, they found one pepsin molecule would cleave the protein substrate multiple times without dissociating from it, thereby generating intermediate peptide products following a zipper mechanism. They concluded that the pepsin hydrolysis can be between two phases of reaction and it was not clear if the rate of decay of the starting substrate followed first order kinetics for both phases.

The results obtained from this study showed that increasing the hydrolysis time (from 1 to $4 \mathrm{~h}$ ) (400\%) increased the protein yield by $16.45-50.82 \%$ depending upon the fish part and enzyme concentration used, as shown in (Table 8). Increasing the hydrolysis time 4 -folds for a small increase in protein yield will increase the capital and operating costs of production. A shorter reaction time will allow more throughput and/or reduce the volume of the reactor thereby reducing the cost of protein extraction. Therefore, a $1 \mathrm{~h}$ hydrolysis time for protein extraction is recommended.

\section{Fish Parts}

The results from weight composition indicated that the average weight of whole fish was $487.11 \mathrm{~g}$ and fish part was between 37.12 $77.14 \mathrm{~g}$. The chemical analyses results indicated that the highest amount of protein was present in whole fish (15.57\%) and the protein content in the fish parts ranged from $12.18-14.16 \%$. After hydrolysis and centrifugation, four layers were observed: upper oil layer, lightlipid layer, soluble clear protein layer and bottom sludge layer. Similar observations were reported by Spinelli et al. and Gildberg [29,30]. The protein hydrolysate was spray dried to obtain protein powder to determine the protein yield as described. The amount of protein recovered depended upon the amount of protein present in the raw material and the hydrolysis conditions (enzyme concentration and hydrolysis time). The protein and oil recovery from whole fish (WF), fin, tail, skin and gut (FTSG), head (H) and frame (F) increased with increases in the enzyme concentration (from $0.5 \%$ to $2.0 \%$ ) and the reaction time (from 1 to $4 \mathrm{~h}$ ). The results indicated that the highest protein yield was obtained from whole fish (WF). The amount of protein obtained from fish waste (frames $(\mathrm{F})$, head $(\mathrm{H})$ and fin, tail, skin and gut (FTSG)) was lower than the whole fish (WF). However, fish wastes (together) can be utilized for the extraction of proteins without any segregation of fish waste parts during fish processing. The recommended extraction parameters for the protein and oil extraction from mackerel fish waste are shown in (Table 9).

Response surface methodology is a collection of statistical and mathematical techniques used for developing, improving and optimizing processes. Diniz and Martin [21] used response surface methodology to describe the optimum conditions for the protein extraction from dog fish (Squalus acanthias) using alcalase. The results indicated that a $\mathrm{pH}$ range of $8-8.5$ and a temperature range of $50-60^{\circ} \mathrm{C}$ and enzyme concentration of $3.6 \%$ were optimal for alcalase-assisted hydrolysis. Gbogouri et al. [10] hydrolyzed salmon and reported a protein recovery of $71.0 \%$ at a $5.5 \%$ enzyme concentration, a $\mathrm{pH}$ of 8 and a temperature of $58^{\circ} \mathrm{C}$ after $2 \mathrm{~h}$, which is less than the protein yield $(76.30 \%)$ achieved at $2 \%$ enzymeconcentration in this study. This agrees with the findings of other researchers [20,21]. Guerard et al. [20] extracted proteins from yellowfin tuna (Thunnus albacares) using alcalase $(0.2-3 \% \mathrm{w} / \mathrm{w})$ at a $\mathrm{pH}$ of 8.0 and a temperature of $55^{\circ} \mathrm{C}$ for $6 \mathrm{~h}$ 
and obtained the highest protein recovery at 3\% enzyme concentration. However, increasing the enzyme concentration beyond $1 \%$ only slightly increased the protein yield.

Beaulieu et al. [31] extracted proteins from Atlantic mackerel (Scomber scombrus) using protamex under optimum conditions $\left(0.001 \%\right.$ enzyme concentration, a $\mathrm{pH}$ of 8 and a temperature of $40^{\circ} \mathrm{C}$ for $120 \mathrm{~min}$ ) and achieved $77.8 \%$ recovery, which is similar to the protein recovery $(76.30 \%)$ achieved from whole fish in this study.

Shahidi et al. [19] extracted proteins from capelin (Mallotus villosus) fish using four different enzymes including alcalase $(1.05 \%$ $(\mathrm{w} / \mathrm{w}))$, Neutrase $(1.05 \%(\mathrm{w} / \mathrm{w}))$, papain $(0.14 \%(\mathrm{w} / \mathrm{w}))$ and endogenous enzymes. The results indicated that the capelin treated with alcalase gave a superior protein recovery of $70.6 \%$ after $120 \mathrm{~min}$ of hydrolysis compared to those of 51.6, 57.1 and $22.9 \%$ from Neutrase, papain and endogenous enzymes, respectively and is less than the protein yield (76.30\%) achieved at $2 \%$ enzyme concentration but it is similar to the protein yield $(71.16 \%)$ achieved at $1 \%$ enzyme concentration from whole fish in this study.

Vieira et al. [8] reported a protein recovery yield of $61.9,44.9$ and $70.1 \%$ using papain, pepsin and fungal protease at $0.5 \%$ from Brazilian lobster heads after $5 \mathrm{~h}$ of hydrolysis. Bhaskar et al. [32] extracted proteins from visceral waste of catla (Catla catla) using alcalase under optimal condition (enzyme concentration of $1.5 \%$, a $\mathrm{pH}$ of 8.5 , a temperature of $50^{\circ} \mathrm{C}$ for $135 \mathrm{~min}$ ) and achieved a protein yield of $71.54 \%$. Bhaskar and Mahendrakar [11] extracted proteins from visceral waste of catla (Catla catla) using multifect-neural under optimal condition (enzyme concentration of $1.25 \%$, temperature of $55^{\circ} \mathrm{C}$ for $165 \mathrm{~min}$ ) and achieved a protein yield of $70.54 \%$. Holanda and Netto [33] recovered protein from shrimp processing waste using alcalase and pancreatin (enzyme concentration of $3 \%$, a temperature of $60^{\circ} \mathrm{C}$ for $30 \mathrm{~min}$ ) and achieved a protein yield of 59.50 and $50.55 \%$, respectively. Alcalase also recovered $18 \%$ more proteins than pancreatin. The protein yields from these studies are similar to the protein yield achieved at $2 \%$ enzyme concentration in this study.

Ovissipour et al. [12] reported that the time and temperature plays an important role in determining the protein yield using alcalase from Persian sturgeon. The results indicated that when the time was increased from 30 to $205 \mathrm{~min}$, the protein recovery increased by $9.91 \%$ and the yield was $38.38 \%$ at $35^{\circ} \mathrm{C}$. When the temperature increased from 35 to $55^{\circ} \mathrm{C}$, the protein recovery increased by $61.43 \%$ and the protein recovery was $61.96 \%$ at $205 \mathrm{~min}$, indicating the highest protein yield was obtained at $55^{\circ} \mathrm{C}$ and $205 \mathrm{~min}$ which is lesser than the protein recovery $(76.30 \%)$ achieved at $2 \%$ enzyme concentration from whole fish in this study.

The maximum protein recovery was obtained at $4 \mathrm{~h}$ and $55^{\circ} \mathrm{C}$ for whole fish (WF), fin, tail, skin and guts (FTSG), head (H), and frames (F) are similar to those reported by Guerard et al. [20] and Kristinsson and Rasco (2000) [9]. The highest protein yield (76.30\%) from whole fish (WF) at $2 \%$ enzyme concentration after $4 \mathrm{~h}$ of hydrolysis was superior to those reported by Gbogouri et al., Ovissipour et al. and Shahidi et al. $[10,12,19]$.The protein yield at $2 \%$ enzyme concentration and $4 \mathrm{~h}$ hydrolysis from fin, tail, skin and guts (FTSG), head (H) and frame (F) were similar to those reported by Vieira et al., Bhaskar et al., Bhaskar and Mahendrakar and superior to those report by Holanda and Netto $[8,11,32,33]$.

\section{Conclusions}

The effects of the alcalase enzyme concentration $(0.5,1$ and $2 \%)$ and time $(1,2,3$ and $4 \mathrm{~h})$ on the extraction of proteins from the whole fish (WF) and fish waste (head (H), frame (F), fin, tail, skin and gut (FTSG)) were studied. The protein yield increased with increases in enzyme concentration (from 0.5 to $2 \%$ ) for the whole fish and fish waste parts because the enzyme molecules become associated with the fish particles, thereby releasing more protein molecules into the system. The results indicated that increasing the enzyme concentration by $400 \%$ (from 0.5 to $2 \%$ ) increased the protein yield by $3.13-43.52 \%$ depending upon the fish part and reaction time used. Increasing the enzyme concentration for a small increase in protein yield seems unjustified. Therefore, the concentration of $0.5 \%$ should be used for the protein extraction unless the enzyme is reused or an immobilized reactor is used in order to reduce the cost associated with the enzyme.

The protein yield increased with increases in reaction time $(1,2$, 3 and $4 \mathrm{~h}$ ) for the whole fish and fish waste parts. The protein yield increased rapidly in the first $1.5 \mathrm{~h}$ and then increased slowly until the hydrolysis was stopped at $4 \mathrm{~h}$. The highest protein yield was obtained at 4 $\mathrm{h}$ from the whole fish and fish waste. The results showed that increasing the hydrolysis time from 1 to $4 \mathrm{~h}(400 \%)$ increased the protein yield by $16.45-50.82 \%$ depending upon the fish part and enzyme concentration used. Increasing the hydrolysis time 4 folds for a small increase in protein yield will increase the capital and operating costs of production. A shorter reaction time will allow more throughput and/or reduce the volume of the reactor thereby reducing the cost of protein extraction. Therefore, a $1 \mathrm{~h}$ hydrolysis time for protein extraction is recommended.

The results indicated that the highest protein yield was obtained from whole fish (WF). The amount of protein obtained from fish waste (frames (F), head (H) and fin, tail, skin and gut (FTSG)) was lower than the whole fish (WF). The total fish wastes (all parts together) can be utilized for the extraction of proteins without any segregation of fish waste parts during fish processing.

\section{Acknowledgement}

The research was supported by the Natural Sciences and Engineering Research Council (NSERC) of Canada

\section{References}

1. FOC (2011) Fisheries and Oceans Canada. Statistics for commercial landings and aquaculture.

2. Statistics Canada (2013)

3. Statistics Canada (2012) Human Activity and the Environment: Waste Management in Canada. Statistics Canada, Catalogue Number: 16-201-X

4. Statistics Canada (2009) Human Activity and the Environment: Annual Statistics. Statistics Canada, Catalogue Number: 16-201-X.

5. Windsor ML (2001) Fish protein concentrate. Food and Agricultural Organization of United Nations, Torry Research Station, Torry Advisory Note No. 39.

6. Gildberg A (1994) Enzymic processing of marine raw materials. Process Biochem 28: 1-15.

7. Himonides TA, Taylor KDA, Morris AJ (2011) Enzymatic Hydrolysis of Fish Frames using Pilot Plant Scale Systems. FNS 2: 586-593.

8. Vieira GHF, Martin MA, Saker-Sampaiao S, Omar S, Goncalves RCF (1995) Studies on the enzymatic hydrolysis of Brazilian lobster (Panulirus spp) processing wastes. J Sci Food Agr 69: 61-65.

9. Kristinsson HG, Rasco BA (2000) Fish protein hydrolysates: production biochemical, and functional properties. Crit Rev Food Sci Nutr 40: 43-81.

10. Gbogouri GA, Linder M, Fanni J, Parmentier M (2004) Influence of Hydrolysis Degree on the Functional Properties of Salmon Byproducts Hydrolysates. J Food Sci 69: C615-C622.

11. Bhaskar N, Mahendrakar NS (2008) Protein hydrolysate from visceral waste 
Citation: Ramakrishnan VV, Ghaly AE, Brooks MS, Budge SM (2013) Extraction of Proteins from Mackerel Fish Processing Waste Using Alcalase Enzyme. J Bioprocess Biotech 3: 130 doi: 10.4172/2155-9821.1000130

Page 9 of 9

proteins of Catla (Catla catla): optimization of hydrolysis conditions for a commercial neutral protease. Bioresour Technol 99: 4105-4111.

12. Ovissipour M, Abedian A, Motamedzadegan A, Rasco B, Safari R, et al. (2009) The effect of enzymatic hydrolysis time and temperature on the properties of protein hydrolysates from Persian sturgeon (Acipenser persicus) viscera. Food Chem 115: 238-242.

13. Fukuda $H$, Kondo A, Noda $H$ (2001) Biodiesel fuel production by transesterification of oils. J Biosci Bioeng 92: 405-416.

14. Shimada $Y$, Watanabe $Y$, Sugihara A, Tominaga $Y$ (2002) Enzymatic alcoholysis for biodiesel fuel production and application of the reaction to oil processing. $J$ Mol Catal B-Enzym 17: 133-142.

15. Gog A, Roman M, Tosa M, Paizs C, Irimie FD (2012) Biodiesel production using enzymatic transesterification- Current state and perspectives. Renew Energ 39: 10-16.

16. Yang Z, Galsius M, Xu X (2012) Enzymatic Transesterification of Ethyl Ferulate with Fish Oil and Reaction Optimization by Response Surface Methodology. Food Technol Biotech 50: 88-97.

17. Gerhardt P, Murray RGE, Wood WA, Krieg NR (1994) Methods for general and molecular bacteriology, ASM Washington DC, 518.

18. Hoyle NT, Merritt JH (1994) Quality of Fish Protein Hydrolysates from Herring (Clupea harengus). J Food Sci 59: 76-79.

19. Shahidi F, Han XQ, Synowiecki J (1995) Production and characteristics of protein hydrolysates from capelin (Mallotus villosus). Food Chem 53: 285-293.

20. Guerard F, Dufosse L, De La Broise D, Binet A (2001) Enzymatic hydrolysis of proteins from yellowfin tuna (Thunnus albacores) wastes using Alcalase. $\mathrm{J} \mathrm{Mol}$ Catal B-Enzym 11: 1051-1059.

21. Diniz FM, Martin AM (1996) Use of response surface methodology to describe the combined effects of $\mathrm{pH}$, temperature and $\mathrm{E} / \mathrm{S}$ ratio on the hydrolysis of dogfish (Squalus acanthias) muscle. Int J Food Sci Tech 31: 419-426.

22. Guerard F, Guimas L, Binet A (2002) Production of tuna waste hydrolysates by a commercial neutral protease preparation. J Mol Catal B-Enzym 19-20: 489-498.

23. Benjakul S, Morrissey MT (1997) Protein Hydrolysates from Pacific Whiting Solid Wastes. J Agric Food Chem 45: 3423-3430.

24. Gonzàlez-Tello P, Camacho F, Jurado E, Paez MP, Guadix EM (1994) Enzymatic hydrolysis of whey proteins: I. Kinetic Models. Biotechnol Bioeng 44: 523-528.

25. Marquez MC, Vazquez MA (1999) Modeling of enzymatic protein hydrolysis Process Biochem 35: 111-117.

26. Moreno MCM, Cuadrado VF (1993) Enzymic hydrolysis of vegetable proteins: mechanism and kinetics. Process Biochem 28: 481-490.

27. Liaset B, Lied E, Espe M (2000) Enzymatic hydrolysis of by-products from the fish-filleting industry; chemical characterization and nutritional evaluation. J Sci Food Agr 80: 581-589.

28. Choisnard L, Froidevaux $\mathrm{R}$, Nedjar-Arroume N, Lignot B, Vercaigne-Marko $D$ et al. (2002) Kinetic study of the appearance of an anti-bacterial peptide in the course of bovine haemoglobin peptic hydrolysis. Biotechnol Appl Biochem 36 187-194.

29. Spinelli J, Dassow JA (1982) Fish Proteins: their modification and potential use in the food industry. In: Chemistry and Biochemistry of Marine Food Products. AVI publishing Company, Westport, CT, 13-25

30. Gildberg A (1992) Recovery of proteinases and protein hydrolysates from fish viscera. Bioresource Technol 39: 271-276.

31. Beaulieu L, Thibodeau J, Bryl P, Carbonneau ME (2009) Proteolytic processing of Atlantic mackerel (Scomber scombrus) and biochemical characterisation of hydrolysates. Int J Food Sci Tech 44: 1609-1618.

32. Bhaskar N, Benila T, Radha C, Lalitha RG (2008) Optimization of enzymatic hydrolysis of visceral waste proteins of Catla (Catla catla) for preparing protein hydrolysate using a commercial protease. Bioresour Technol 99: 335-343.

33. Holanda HD, Netto FM (2006) Recovery of Components from Shrimp (Xiphopenaeus kroyeri) Processing Waste by Enzymatic Hydrolysis. J Food Sci 71: C298-C303. 